\section{Exclusion of a disease relevant role of PAX4 in the aetiology of Silver-Russell syndrome: screening for mutations and determination of imprinting status}

EDITOR-Silver-Russell syndrome (SRS) describes a uniform malformation syndrome characterised by intrauterine and postnatal growth retardation (IUGR/PGR), asymmetry of the head and limbs, a small triangular face, and other less constant features. The majority of the 400 cases described so far occurred sporadically, but some familial cases indicate a genetic cause of the disease. In rare cases, chromosomal aberrations have been found. Although no uniform pattern is apparent, ${ }^{1}$ five cases have recently been reported involving chromosome $7 .^{2-6} \mathrm{~A}$ subset of $7-10 \%$ of SRS patients shows maternal uniparental disomy (mUPD) for the whole of chromosome $7,{ }^{7}$ thus indicating the involvement of at least one imprinted gene on this chromosome. Mutations in this gene or imprinting mutations may contribute to the SRS phenotype. So far, two imprinted genes localised in 7q32 (MEST/PEG1, $C O P-G 2$ ) have been excluded as candidate genes for SRS. ${ }^{89}$

PAX4 is a member of a highly conserved gene family, ${ }^{10}$ and has been mapped to $7 \mathrm{q} 32 .{ }^{11}$ Evidence of the crucial role of $P A X$ genes in organogenesis and in differentiation is provided by mouse developmental mutants ${ }^{12}$ as well as by human diseases ( $P A X 2$, kidney abnormalities, optic nerve coloboma; $P A X 3$, Waardenburg syndrome types I and III; $P A X 5$, small lymphotic lymphomas; $P A X 6$, aniridia; $P A X 9$, optic nerve coloboma)..$^{13} 14$

A role for PAX4 in the aetiology of diabetes type II has recently been dismissed by investigations in a group of French patients as well as in a population of 116 unrelated Ashkenazi Jews affected by the disease. ${ }^{15}{ }^{16}$ Furthermore,
PAX4 has been ruled out as a possible candidate gene for the Wolcott-Rallison syndrome. ${ }^{17}$

The PAX4 gene product contains two DNA binding motifs, a paired domain which consists of three alpha helices, and a paired type homeodomain with a helix turn helix motif; owing to its localisation in the nucleus and its ability to bind DNA, it might serve as a transcription factor. ${ }^{10}$

$P A X 4$ is expressed predominantly in placenta and skeletal muscle; fewer transcripts have been observed in the heart. ${ }^{15}$ Detection of Pax 4 transcripts in the early pancreas of mice in combination with results of knock out experiments indicate an important role for Pax4 during development: mice homozygously deficient for Pax4 suffer from growth retardation and dehydration at birth and die within three days. ${ }^{18}$ Its expression in pancreatic island progenitor cells, which are the common progenitor for beta and delta cells, controls the initial processes of endocrine differentiation. In the mature endocrine pancreas, it might contribute to the maintenance of the differentiated state of beta cells, since then Pax4 is restricted to this cell population. ${ }^{18}$

So far, there is no information available about the imprinting status of $P A X 4$. Since imprinted genes tend to be clustered, ${ }^{9}$ the close proximity of PAX4 to MEST/PEG1 and $C O P-G 2$, which have recently been shown to be paternally expressed, renders its imprinting possible. Taking into account its function, the very restricted spatial and temporary pattern of expression during embryogenesis, and its localisation in $7 \mathrm{q} 32, \mathrm{PAX} 4$ was considered to be a good candidate gene for SRS.

Our study population consisted of 50 SRS patients in which diagnosis was ascertained according to Wollmann et $a l .{ }^{1}$ Cytogenetic analyses by $\mathrm{G}$ banding on peripheral blood lymphocyte cultures of these patients did not show any abnormalities. A maximum of 53 unrelated, healthy probands of German origin were investigated as controls. Genomic DNA from patients and controls was isolated

Table 1 Data on the PAX4 fragments analysed in this study and PCR conditions

\begin{tabular}{|c|c|c|c|c|c|}
\hline $\begin{array}{l}\text { Exon size } \\
(b p)\end{array}$ & Primer $\left(5^{\prime}>3^{\prime}\right)$ & $\begin{array}{l}\text { Cosmid AC000359 } \\
\text { (exon positions) }\end{array}$ & $\begin{array}{l}m R N A \\
A F 043978\end{array}$ & $\begin{array}{l}T a \\
\left({ }^{\circ} C\right)\end{array}$ & $\begin{array}{l}\mathrm{MgCl}_{2} \\
(\mathrm{mM})\end{array}$ \\
\hline 5'UTR & $\begin{array}{l}\text { atacctctgtctcacgccca } \\
\text { ggcttcctgtccccatcactg }\end{array}$ & $31609-31362$ & $1-206$ & 63.5 & 1,5 \\
\hline $1(120)$ & $\begin{array}{l}\text { atacctctgtctcacgccca } \\
\text { ggcttcctgtccccatcactg }\end{array}$ & $\begin{array}{l}31074-30881 \\
(31042-30923)\end{array}$ & $207-326$ & 63.5 & 1,5 \\
\hline $2(216)$ & $\begin{array}{l}\text { catgcctcacctctccetg } \\
\text { tcttttccagccccagtgtg }\end{array}$ & $\begin{array}{l}30653-30363 \\
(30617-30402)\end{array}$ & $327-542$ & 63.5 & 1,5 \\
\hline $3(76)$ & $\begin{array}{l}\text { atctctccactcaacaccct } \\
\text { acgagaaagggctttgagaa }\end{array}$ & $\begin{array}{l}30110-29927 \\
(30079-30004)\end{array}$ & 543-618 & 58 & 1,5 \\
\hline $4(126)$ & $\begin{array}{l}\text { atctgaccagaggaatcacc } \\
\text { tgtcacactgaggactctct }\end{array}$ & $\begin{array}{l}29460-29231 \\
(29043-29278)\end{array}$ & $619-744$ & 61 & 1,5 \\
\hline $5(83)$ & $\begin{array}{l}\text { ttggggttgtagcaggtggg } \\
\text { cttcctccttgtggtttgta }\end{array}$ & $\begin{array}{l}29148-28929 \\
(29053-28971)\end{array}$ & $745-827$ & 60 & 1,5 \\
\hline $6(70)$ & $\begin{array}{l}\text { gatgtcaggcccaaggaagggtcaa } \\
\text { gatgactgagcggcagatggatg }\end{array}$ & $\begin{array}{l}28730-28501 \\
(28612-28543)\end{array}$ & $828-897$ & 67 & 1,5 \\
\hline $7(56)$ & $\begin{array}{l}\text { caaccttcctgectctcacc } \\
\text { cccatgagcccttcagtctt }\end{array}$ & $\begin{array}{l}27610-27420 \\
(27529-27474)\end{array}$ & $898-953$ & 65 & 1,5 \\
\hline $8(142)$ & $\begin{array}{l}\text { ctggaagctaaggttcttct } \\
\text { tcagtcgaccctcctacat }\end{array}$ & $\begin{array}{l}27243-27011 \\
(27205-27064)\end{array}$ & 954-1095 & 61 & 1,5 \\
\hline $9(143)$ & $\begin{array}{l}\text { aagctctctctatttgtccc } \\
\text { cacacaggagggagcatca }\end{array}$ & $\begin{array}{l}27660-26407 \\
(26735-26593)\end{array}$ & $1096-1238$ & 65 & 1,5 \\
\hline 3'UTR1 & $\begin{array}{l}\text { cggcccactactgtatggct } \\
\text { agagtgggcataggggtgctcata }\end{array}$ & $26760-26407$ & $1239-2020$ & 59 & 1,5 \\
\hline 3'UTR2 & $\begin{array}{l}\text { tcgatgcctctctggcgcat } \\
\text { aatgccatgatataatatca }\end{array}$ & $26451-26050$ & & 55 & 3 \\
\hline 3'UTR3 & $\begin{array}{l}\text { tgtatgtatgtgtgcatgcg } \\
\text { cccctggagcatgtataaat }\end{array}$ & $26122-25773$ & & 53 & 3 \\
\hline
\end{tabular}

$\mathrm{Ta}$, annealing temperature; $\mathrm{MgCl}_{2}$, final concentration. 


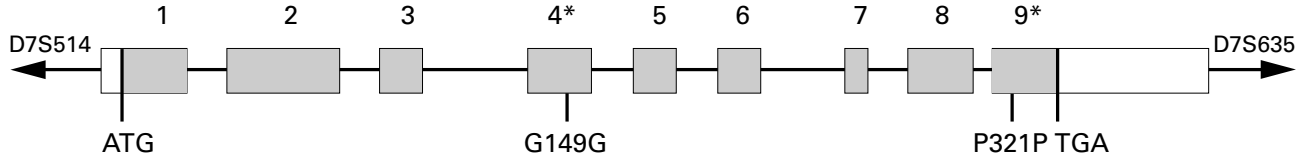

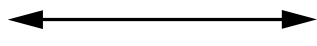

Paired domain

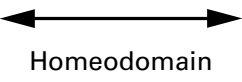

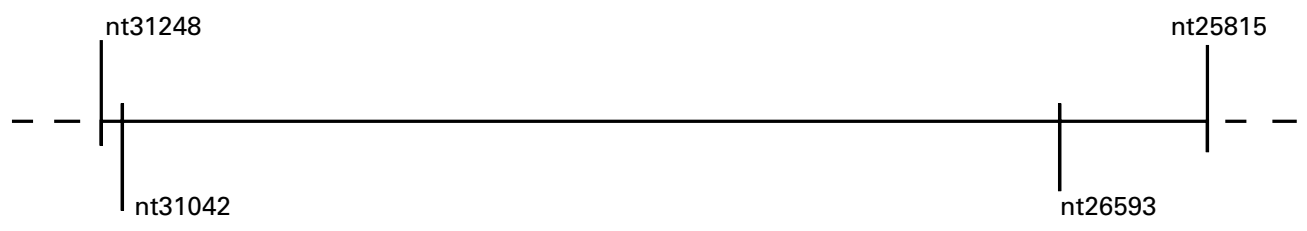

AC000359 (g1572c264) $5.5 \mathrm{~kb}$

Figure 1 Schematic representation of the PAX4 gene ${ }^{15} 17$ and the newly detected polymorphisms.

from peripheral blood lymphocytes. RNA was isolated from five SRS patients using the QiaRNeasy Blood Kit.

Information about the genomic structure of the $P A X 4$ gene was obtained by performing a BLAST search in public databases with mRNA g5453849 17 as a probe. The identified PAC clone g1572c264 (GenBank Accession No AC000359) was used to choose PCR primers located in introns. Updating of the exon/intron structure and coding/ non-coding regions was performed according to the more detailed information published by Tao et al. ${ }^{15}$

For cDNA synthesis, RNA probes $(1 \mu \mathrm{g})$ were treated with DNase I, subsequently denatured at $94^{\circ} \mathrm{C}$ for five minutes, and immediately chilled on ice. Reverse transcription was carried out using random hexanucleotide primers $(1.5 \mu \mathrm{g}), 1 \times$ first strand buffer, 1 vol dithiothreitol, 10 $\mathrm{mmol} / 1$ each dNTP, $200 \mathrm{U}$ Superscript reverse transcriptase (Gibco BRL), and $80 \mathrm{U}$ RNase inhibitor (Gibco $\mathrm{BRL}$ ). These were added to a final volume of $38 \mu \mathrm{l}$, incubated at $42^{\circ} \mathrm{C}$ for one hour, and the reaction terminated by heating for 15 minutes. To detect possible DNA contamination of the RNA samples, we subjected half of each probe to the reaction without the addition of reverse transcriptase.

To produce overlapping PCR fragments of the coding region, 13 sets of primers were chosen encompassing the whole coding region consisting of 9 exons, the exon/intron boundaries, as well as the 5 ' and $3^{\prime}$ untranslated regions. Fragment sizes were between 200 and $440 \mathrm{bp}$.

In case of detected variants, up to 50 SRS patients were investigated for each fragment as well as a maximum of 53 controls. Standard PCR was carried out in a total volume of $25 \mu \mathrm{l}$ containing $80 \mathrm{ng}$ of genomic DNA, $20 \mathrm{pmol}$ of each primer, $50 \mathrm{mmol} / 1 \mathrm{KCl}, 10 \mathrm{mmol} / 1$ Tris- $\mathrm{HCl}(\mathrm{pH}$ 8.3), $1.5-3 \mathrm{mmol} / 1 \mathrm{MgCl}_{2}, 0.01 \%$ gelatine, $200 \mu \mathrm{mol} / 1$ of

Table 2 Detection and characterisation of new DNA sequence variants in the human PAX4 gene

\begin{tabular}{|c|c|c|c|}
\hline \multirow[b]{2}{*}{ Fragment } & \multirow[b]{2}{*}{ Nucleotide position* } & \multicolumn{2}{|c|}{ Allele frequency (chromosomes) } \\
\hline & & Controls & SRS patients \\
\hline Exon 4 & $\begin{array}{l}\mathrm{nt} 29366 \mathrm{G}>\mathrm{A} \\
(\mathrm{G} 149 \mathrm{G})\end{array}$ & $0 / 56$ & $1 / 88$ \\
\hline Exon 9 & $\begin{array}{l}\text { nt26663G }>\text { T } \\
\text { (P321P) }\end{array}$ & $15 / 106$ & $18 / 88$ \\
\hline 3'UTR & $\begin{array}{l}\mathrm{nt} 26382 \mathrm{C}>\mathrm{T} \\
\mathrm{nt} 26112 \mathrm{~A}>\mathrm{G}\end{array}$ & $\begin{array}{l}10 / 66 \\
11 / 14\end{array}$ & $\begin{array}{l}28 / 100 \\
43 / 66\end{array}$ \\
\hline
\end{tabular}

^Nucleotide positions based on cosmid g1572c264 (AC000359). each dNTP, and 1 U Taq Polymerase (Gibco). Primer sequences and PCR conditions are listed in table 1.

Mutation screening was performed by single strand conformation polymorphism analysis (SSCA): $3 \mu \mathrm{l}$ of PCR products were mixed with $7 \mu \mathrm{l}$ of denaturing solution containing $80 \%$ deionised formamide, $0.0125 \%$ bromophenol blue, and $0.75 \%$ Ficoll 400 , and denatured for five minutes at $94^{\circ} \mathrm{C}$. Samples were subsequently chilled on ice and then loaded on $10 \%(49: 1)$ polyacrylamide gels with and without glycerol (5\%). They were allowed to run for 16-18 hours at $7 \mathrm{~V} / \mathrm{cm}$, both at $4^{\circ} \mathrm{C}$ and room temperature. Bands were visualised by silver staining.

For sequencing, symmetrical PCR products were purified by ultrafiltration using the Qiaquick PCR purification kit and concentrated from 100 to $40 \mu$ l. One of the two strands was then selectively amplified from $70 \mathrm{ng}$ of the purified products using the BigDyeTerminator kit (Perkin Elmer).

Excluding null alleles, the alleles of polymorphic loci show codominance, providing complete genotypic information from which estimates of Hardy-Weinberg deviation and genetic structuring of groups can readily be calculated. The statistical significance of Hardy-Weinberg deviation, intergroup differences of allele, and genotype frequencies were determined using exact test procedures in Raymond and Route's GENEPOP package. ${ }^{19} 20$

We screened the nine exons and the 3'UTR of PAX4 for disease related mutations and variants useful for expression studies (fig 1, table 1 ).

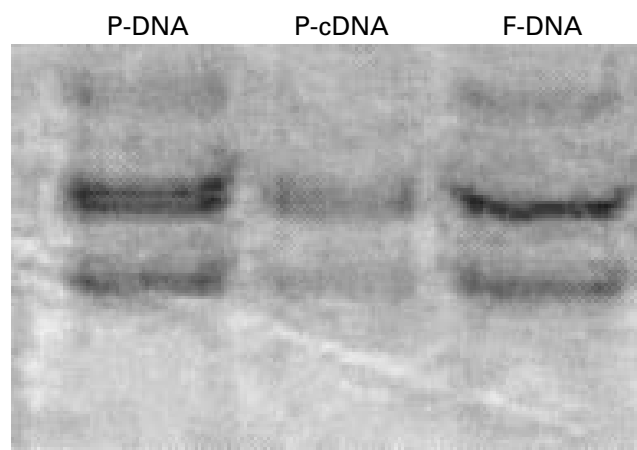

Figure 2 SSCA of polymorphism nt26382C $>$ T in 3'UTR1: DNA and cDNA of a heterozygous SRS patient show the same band pattern; the father homozygous for the wild type allele shows a different pattern ( $P$, SRS patient; F, father). 
Using SSCA, we identified four polymorphisms distributed in the coding region and the 3'UTR (table 2, fig 2); however, we may have missed some variants relying on SSCA as the only screening method since its sensitivity is less than $100 \%$. The variant in exon 4 (nt29366G $>$ A) was very rare, thus emphasising the strong conservation of this gene, while the variation in exon 9 (nt26663G>T) occurred frequently as well as the two polymorphisms in the 3'UTR (nt26382C>T, nt26112A>G). Both base pair substitutions in the coding region were identified as silent mutations (G149G, P321P).

The patterns of allele and genotype frequencies were highly consistent for all loci and for both the patient and control group. The observed genotype distributions showed no significance compared with Hardy-Weinberg expectation in the patient or in the control group. Furthermore, the allele and genotype frequencies did not differ significantly between the patient and control group for all loci $(\mathrm{p}>0.06)$.

To determine the imprinting status of PAX4 and to distinguish between mono- and biparentally expressed alleles, the identified variants were investigated at the RNA level: Two SRS patients heterozygous for polymorphisms nt $26382 \mathrm{C}>\mathrm{T}$ and nt26663G $>\mathrm{T}$, respectively, showed no reduction to homozygosity at the cDNA level; thus, biallelic expression of PAX4 in peripheral blood lymphocytes could be shown. Additional proof came from a SRS patient with mUPD7, since several fragments of the PAX4 transcript could be amplified from RNA extracted from peripheral blood lymphocytes, thus excluding the possibility of maternal imprinting of this gene. So far, these results allow no conclusions about any tissue or time restricted pattern of genomic imprinting for $P A X 4$, and further investigations will have to follow.

To sum up, we exclude $P A X 4$ as a major candidate gene for SRS, since we could not detect any disease relevant mutations in our study population. Nevertheless, there remains the possibility that we missed some rare mutations, which might play a relevant role in a small number of SRS patients, since SRS is likely to originate from a heterogeneous background.

In addition to MEST/PEG1 and COP-G2, PAX4 is a further gene in $7 \mathrm{q} 32$ that has been excluded as a candidate gene for SRS. Recent publications describe duplications of 7p12-p14 in SRS patients, indicating that putative SRS genes are located in this region, which might be an important argument to focus further investigations on the short arm of chromosome 7 .

This work was supported by the START research programme of the Technical University of Aachen and a grant from Pharmacia \& Upjohn, Sweden. The authors wish to thank the "Bundesverband Kleinwüchsiger Menschen" and the SRS families who participated in this study.
SUSANNE MERGENTHALER* KATJA EGGERMANN ${ }^{\star}$ JÜRGEN TOMIUK† MICHAEL B RANKE $\ddagger$ HARTMUT A WOLLMANN $\ddagger$ THOMAS EGGERMANN

*Institute of Human Genetics, Technical University, Pauwelsstrasse 30, 52074 Aachen, Germany

†Institute of Human Genetics, University of Tübingen, Germany

$\ddagger$ University Children’s Hospital, Tübingen, Germany

Correspondence to: Dr Mergenthaler,

smergenthaler@post.klinikum.rwth-aachen.de

1 Wollmann HA, Kirchner T, Enders H, Preece MA, Ranke MB. Growth and symptoms in Silver-Russell syndrome: review on the basis of 386 patients. Eur F Pediatr 1995;154:958-68.

2 Miyoshi O, Kondok T, Tanada H, Otsaka K, Matsumoto T, Niikana N. 47,XX,UPD(7)mat, $+r(7)$ pat/46,XX,UPD(7)mat mosaicism in a girl with Silver-Russell syndrome (SRS): possible exclusion of the putative SRS gene from 7p13-q11 region. $\mathcal{F M e d}$ Genet 1999;36:326-9.

3 Joyce CA, Sharp A, Walker JM, Bullman H, Temple K. Duplication of 7p12.1-p13, including GRB10 and IGFBP1 in a mother and daughter with 7p12.1-p13, including GRB10 and IGFBP1 in a mother and daugh

4 Wakeling E, Monk D, Hitchis M, Proud V, Stanier P, Preece MA, Moore GE. Duplication of $7 \mathrm{p} 11.2-\mathrm{p} 12$ including GRB10 in Silver-Russell GE. Duplication of 7p11.2-p12 includin
syndrome. Am f Hum Genet 2000;66:36-46.

5 Fernandez BA, Tertina I, Nakabayashi K, Proud V, Weksberg R, Scherer SW. Russell-Silver syndrome: identification of a candidate region on the short arm of chromosome 7. Am F Hum Genet 1999;65:A295.

6 Eggerding FA, Schonberg SA, Chehab FF, Norton ME, Cox VA, Epstein CJ. Uniparental isodisomy for paternal $7 \mathrm{p}$ and maternal $7 \mathrm{q}$ in a child with growth retardation. Am F Hum Genet 1994;55:253-65.

7 Kotzot D. Abnormal phenotypes in uniparental disomy (UPD): fundamental aspects and a critical review with bibliography of UPD other than 15 . Am F Med Genet 1999;82:265-74.

8 Riesewiik AM, Blagitko N, Schinzel AA, Hu L, Schulz U, Hamel BCJ, Ropers $\mathrm{HH}$, Kalscheuer VM. Evidence against a major role of PEG1/MEST in Silver-Russell syndrome. Eur 7 Hum Genet 1998;6:114-20.

9 Blagitko-Dorfs N, Schulz U, Schinzel AA, Ropers HH, Kalscheuer VM. $\gamma 2-C O P$, a novel imprinted gene on chromosome $7 \mathrm{q} 32$, defines a new imprinting cluster in the human genome. Hum Mol Genet 1999;8:2387-96.

10 Stuart TE, Kiousssi C, Gruss P. Mammalian PAX Genes. Annu Rev Genet 1993;27:219-36.

11 Tamura T, Izumikawa Y, Kishino T, Soejima H, Jinno Y, Niikawa N. Assignment of the human PAX4 gene to chromosome band $7 \mathrm{q} 32$ by fluorescence in situ hybridization. Cytogenet Cell Genet 1994;66:132-4

12 Kalousova A, Benes V, Paces J, Paces V, Kozmik Z. DNA-binding and transactivating properties of the paired and homeobox protein PAX4. Biochem Biophys Res Commun 1999;259:510-18.

13 Schuffenhauer S, Leifheit HJ, Lichter P, Peters H, Murken J, Emmerich P. De novo deletion (14)(q11.2q13) including PAX9: clinical and molecular findings. F Med Genet 1999;36:233-6.

14 Busslinger M, Klix N, Pfeffer P, Graninger PG, Kozmik Z. Deregulation of PAX 5 by translocation of the EMU enhancer of the IgH locus adjacent to two alternative PAX5-promoters in a diffuse large-cell lymphoma. Proc Natl Acad Sci USA 1996;93:6129-34.

15 Tao T, Wasson J, Bernal-Mizrachi E, Behn PS, Chayen S, Duprat L, Meyer J, Glaser B, Permutt MA. Isolation and characterisation of the human PAX4 gene. Diabetes 1998;47:1650-3.

16 Dupont S, Vionnet N, Chèvre JC, Gallina S, Dira C, Seiro Y, Yamada Y, Froguel P. No evidence of linkage or diabetes associated mutations in the transcription factors BETA2/NEUROD1 and PAX4 in type II diabetes in transcription factors BETA2/NEUR

17 Bonthron DT, Dunlop N, Barr DGD, El Sanousi AA, Al-Gazali LI. Organisation of the human PAX4 gene and its exclusion as a candidate for the Wolcott-Rallison syndrome. f Med Genet 1998;35:288-92.

18 Sosa-Pineda B, Chowdhury K, Torres M, Oliver G, Gruss P. The PAX4 gene is essential for differentiation of insulin-producing beta-cells in the mammalian pancreas. Nature 1997;386:399-402

19 Raymond M, Rousset F. GENEPOP (version 1.2); a population genetics software for exact tests and ecumemiscism. F Hered 1995;86:485-6.

20 Roff DA, Bentzen P.The statistical analysis of mitochondrial DNA polymorphisms: Chi-square and the problem of small samples. Mol Biol Evol 1989;6:539-45. 